\title{
Sociodemographic and obstetric factors related to low birth weight in the context of early pregnancy
}

Brenda Karoline Santos 1

(iD) https://orcid.org/0000-0003-3734-3827

Viviane Macedo Marinho Barreto 2

iD https://orcid.org/0000-0002-6457-8034

Vinícius Souza Santos 3

https://orcid.org/0000-0002-6833-5486

Neyana Maria Coelho de Souza Prado 4 https://orcid.org/0000-0003-0451-8539

José Rodrigo Santos Silva 5

iD https://orcid.org/0000-0002-1918-7122
Ana Jovina Barreto Bispo 6

(iD) https://orcid.org/0000-0002-6228-768X

Andrea Ferreira Soares 7

D https://orcid.org/0000-0002-1442-6462

1,2,7 Universidade Federal de Sergipe. São Cristóvão, SE, Brasil.

3 Departamento de Morfologia. Universidade Federal de Sergipe. Campus São Cristóvão. Av. Marechal Rondon s.n. Bairro Jardim Roza Elze. São Cristóvão, SE, Brasil. CEP:

49.100-000 E-mail: viniciusouza2017@outlook.com.br

4 Departamento de Enfermagem. Universidade Federal de Sergipe. São Cristóvão, SE, Brasil.

5 Departamento de Estatística e Ciências Atuariais. Universidade Federal de Sergipe. São Cristóvão, SE, Brasil.

${ }^{6}$ Hospital Universitário. Universidade Federal de Sergipe. Aracaju, SE, Brasil.

\begin{abstract}
Objectives: to analyze sociodemographic and obstetric factors that may influence the occurrence of low birth weight in the context of early pregnancy.

Methods: the sample consisted of 232 pregnant teenagers, aged 10-19 years old, were assisted at a public maternity hospital in Aracaju-SE during the period of August 2012 to July 2016. The data collection was conducted through a structured questionnaire.

Results: low birth weight was observed in $41.38 \%$ of the newborns and there was a statistical association between the educational level and the marital status with the occurrence of low birth weight in newborns among teenage mothers, with $p=0.0286$ and $p=0.0247$, respectively.

Conclusions: the socioeconomic factors may contribute to the occurrence of low birth weight in newborns of teenage mothers and teenage pregnancy at this age represents a serious public health problem.
\end{abstract}

Key words Adolescent, Pregnancy, Low birth weight

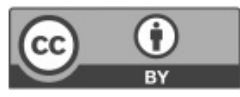




\section{Introduction}

Adolescence is the transition period between childhood and adulthood, a stage that goes from 10 to 19 years old, according to the World Health Organization (1975), being a period of profound transformation in the individual's body, mind and social relationship status. 1,2 Teenage pregnancy has been indicated as a state of vulnerability, in which there are several risk factors that involve in a pregnancy, motherhood and fatherhood, and due to their physical, psychological and social repercussions. ${ }^{3}$

Teenage pregnancy is a condition of psychosocial and health risks, whose most serious repercussions affect young mothers who belong to lowincome social classes. In locations where lowincome families reside, reports of early pregnancy or abortion practices are more common. The low binomial purchasing power / schooling is especially striking, the sooner the teenager initiates sexual practice, it favors the increased risk of an unwanted pregnancy, by not using contraceptive methods. Studies highlight the interferences that early and unexpected pregnancy can cause in a teenage mother's life, such as dropping out of school and the difficulties in a getting a job. ${ }^{3}$

Babies born below 2,500g are considered to be low birth weight newborns, according to WHO (1998). ${ }^{4}$ Studies indicate the main risk factors for the occurrence of this condition are: prematurity, maternal age, low levels of socioeconomic development, nulliparity, multiparity, family and marital fragility, in addition to other biological factors. Low Birth Weight (LBW) represents a risk condition for the child's survival, as it increases infant / neonatal mortality rates, it is considered an important worldwide public health problem.5,6

High proportions of low birth weight live births are generally associated with low levels of socioeconomic development and maternal and child care. There is a strong association between LBW and the low number of prenatal consultations and their late onset, as well as with a low level of schooling, women who did not conclude primary schooling are the most likely to have low birth weight babies at birth ${ }^{7}$ In Brazil, according to official data, $26.8 \%$ of the sexually active population (15-64 years old) started their sexual life before the age of 15 , about $19.3 \%$ of the children born alive in 2010 are children of women aged 19 or younger. ${ }^{8}$ And, according to DATASUS (2011), the proportion of live births with low birth weight in Sergipe was $8.08 \% .{ }^{9}$

Given the relevance of the topic, this study aimed to analyze the sociodemographic and obstetric risk factors that may influence the occurrence of low birth weight in the context of early pregnancy.

\section{Methods}

A descriptive-exploratory study with a quantitative approach was developed with 232 pregnant teenagers, aged 10 to 19 years old and assisted at a public maternity hospital in Aracaju-SE, Brazil, from August 2012 to July 2016. For the data collection, a previously tested structured questionnaire was applied, which focuses on several risk factors for the occurrence of low birth weight, applied during the postnatal follow-up period.

The questionnaire consisted of objective multiple choice and dichotomous questions, containing the following sociodemographic and obstetric variables: origin, adolescent's age, marital status, schooling level, occupation, family income in minimum wages, pregnancy planning, gynecological age, number of pregnancies (parity), number of prenatal consultations and the newborn's weight at birth. For data interpretation, a descriptive analysis was carried out, proceeding to the categorization of the referred variables and obtaining the respective frequencies and percentages, aiming to trace the sociodemographic and obstetric profile of the sample analyzed in the considered period. For inferential analysis, a group of 96 teenage mothers, who had low birth weight newborns, was divided into two subgroups, according to their gynecological age: those who had this outcome in the interval less than or equal to two years and those who had more than two years.

The chi-square and Fisher's exact tests were used in order to verify whether the gynecological age had a significant relation among the independent variables, with $p<0.05$, according to the adapted methodology. 10

The study was approved by the Human Research Ethics Committee at the Universidade Federal de Sergipe, under the document number: 174.677 and CAAE number: 04326512.2.0000.5546. The participation of teenage mothers in this study occurred by signing of the Informed Consent Form by a responsible guardian or on their own.

\section{Results}

In the sample of 232 teenage mothers, it was found that $70.6 \%$ came from the countryside of the State, $63.3 \%$ had not concluded their primary schooling, $73.2 \%$ had family income less than or equal to a minimum wage and $81.4 \%$ had a stable union with 
partner. There was a prevalence of teenage mothers aged 15 to 19 years old with $91.8 \%$ and newborn's weight at birth was less than $2,500 \mathrm{~g}$ was observed in a significant percentage of $41.3 \%$. Unplanned pregnancies were $70.2 \%$ and the lack of paying jobs was $79.3 \%$. In regards to parity, $79.3 \%$ were primiparous, that is, they were in the condition of the first childbirth. About $74.5 \%$ of teenagers reported having at least four prenatal consultations during their pregnancy. As for gynecological age, $59.4 \%$ had a value greater than two years and $40.5 \%$ had a gynecological age less than or equal to 2 years (Table 1).

Among the correlated sociodemographic and obstetric variables, it was observed that bonding with the partner and schooling were related to the occurrence of low birth weight in newborns among teenage mothers, $p=0.024$ and $p=0.028$, respectively (Table 2).

\section{Discussion}

Teenage pregnancy is considered a public health problem worldwide, involving biological, psychological, demographic, economic and social factors. Studies and reflections on the theme are necessary to guarantee well-being and the future of these teenagers and to reduce the occurrence of early pregnancy. 6 In this study, 232 teenagers were interviewed, among which there was a predominance of teenage mothers who did not plan in getting pregnant, concentrated in the age group of 15-19 years old, and most of them came from the countryside of the State, which corroborates with the data research carried out by the Brazilian Institute of Geography and Statistics, IBGE, (2000-2006), in which 20.6\% of live births are children of teenage mothers, between 15-19 years old. When comparing to the local reality and the national data, it was noticed that teenage pregnancy rate prevailed between the age of 15-19 years old. ${ }^{11}$

In regards to family income, there was a predominance of teenage mothers with a monthly family earnings of one minimum wage or less $(73.28 \%$ ). This data agrees with a study carried out through a survey of approximately ten thousand parturients in the first 48 hours after childbirth in public and private maternity hospitals in the city of Rio de Janeiro. 12 The research relates low birth weight and family income, noting that for low birth weight, for example, the proportion varied at $10.7 \%$, for the income category below R $\$ 200.00$, to $5.88 \%$ for the income category above $\mathrm{R} \$ 2,000.00$. It should be noted that when comparing the two outcomes, LBW and perinatal mortality, the latter presents an even more pronounced gradient, with a proportion that is reduced to almost zero (0.4) in the higher income category. Therefore, the socioeconomic disadvantage acts as an important etiological factor, both for prematurity as for LBW, however, the interference of other decisive factors on psychological, behavioral, biological and environmental nature, it must be taken to consideration the reduction on fetal growth and LBW. 12

In relation of the number of prenatal consultations, it was observed that $25.43 \%$ of the mothers had less than 3 consultations, $42.6 \%$ of 4 to 6 consultations and $31.9 \%$ more than 7 consultations, data that are in accordance with a work carried out on 600 newborns at the General Hospital in Caxias do Sul, in which the average of prenatal consultations of low birth weight newborns' mothers was four and in the control group six. This difference must be carefully analyzed because the pregnant women in the case group had less available time to perform prenatal care, due to premature labor, which usually occurs before 32 weeks of gestation, and the smaller number of consultations cannot be the cause of premature birth or LBW, but the consequence. At this stage of life, it is common for teenagers to find it difficult to accept the pregnancy and many of them hide it from their partner and / or family members, extending the beginning of prenatal care. 13

A study demonstrates that pregnancy in the 10 to 14 age group favors the greatest risk for infant morbidity and mortality. The fertility rate in this age group is high, but this group points out risk factors such as gestational disability, observed mainly by the immaturity of the female reproductive system, taking into account these mothers' low gynecological age. The incidence of perinatal mortality, LBW and prematurity are related to problems in the uterine development and childbirth, which could be minimized if these young women had obtained a better education and early prenatal care. ${ }^{14}$

It was found that, in the group of mothers who had low birth weight babies, $79.1 \%$ were primiparous, that is, they were in the condition of the first childbirth, among them $39.4 \%$ had a gynecological age less than or equal to two. A study developed with 77 pregnant women of low socioeconomic level between 15 and 48 years old living in São Paulo, addressed that parity and interpregnancy interval, less than two years or greater than five years, imply risks of different magnitudes for women and the newborns. The exact reason for this correlation is not clearly defined. 5

A hypothesis was launched to explain the relation between short interpregnancy interval and the 
Table 1

Sociodemographic and obstetric profile of teenage mothers assisted at a public maternity hospital in Aracaju / Sergipe, between 2012-2016.

\begin{tabular}{|c|c|c|}
\hline Variables & $\mathbf{N}$ & $\%$ \\
\hline \multicolumn{3}{|l|}{ Origin } \\
\hline Aracaju & 68 & 29.3 \\
\hline Countryside & 164 & 70.6 \\
\hline \multicolumn{3}{|l|}{ Age (years) } \\
\hline $10-14$ & 19 & 8.1 \\
\hline $15-19$ & 213 & 91.8 \\
\hline \multicolumn{3}{|l|}{ Marital status } \\
\hline Stable union & 189 & 81.4 \\
\hline Without stable union & 43 & 18.5 \\
\hline \multicolumn{3}{|l|}{ Schooling level } \\
\hline Did not conclude elementary schooling & 147 & 63.3 \\
\hline Concluded elementary schooling & 17 & 7.3 \\
\hline Did not conclude high school & 49 & 21.1 \\
\hline Concluded high school & 19 & 8.1 \\
\hline \multicolumn{3}{|l|}{ Occupation } \\
\hline Paying job & 21 & 9.0 \\
\hline Non-paying job & 210 & 90.5 \\
\hline Not informed & 1 & 0.4 \\
\hline \multicolumn{3}{|l|}{ Income (minimum wages) } \\
\hline$\leq 1$ & 170 & 73.2 \\
\hline $2-3$ & 44 & 18.9 \\
\hline$>3$ & 18 & 7.7 \\
\hline \multicolumn{3}{|l|}{ Pregnancy (parity) } \\
\hline 1 & 184 & 79.3 \\
\hline$\geq 2$ & 48 & 20.6 \\
\hline \multicolumn{3}{|l|}{ Gynecological age } \\
\hline$\leq 2$ & 94 & 40.5 \\
\hline$>2$ & 138 & 59.4 \\
\hline \multicolumn{3}{|l|}{ Newborn's weight (g) } \\
\hline$<2500$ & 96 & 41.3 \\
\hline$\geq 2500$ & 136 & 58.6 \\
\hline \multicolumn{3}{|l|}{ Prenatal consultation } \\
\hline $1-3$ & 56 & 24.1 \\
\hline $4-6$ & 99 & 42.6 \\
\hline$>7$ & 74 & 31.9 \\
\hline None & 3 & 1.2 \\
\hline \multicolumn{3}{|l|}{ Pregnancy planning } \\
\hline No & 163 & 70.2 \\
\hline Yes & 69 & 29.7 \\
\hline
\end{tabular}


Bivariate analysis of sociodemographic and obstetric risk factors associated with the occurrence of low birth weight among teenage mothers assisted at a public maternity hospital in Aracaju / Sergipe, between 2012-2016.

\begin{tabular}{|c|c|c|c|c|c|}
\hline \multirow[t]{3}{*}{ Variables } & \multicolumn{4}{|c|}{ Gynecological age } & \multirow[t]{3}{*}{$p$} \\
\hline & \multicolumn{2}{|c|}{$\leq 2$} & \multicolumn{2}{|c|}{$>2$} & \\
\hline & $\mathrm{n}$ & $\%$ & $\mathrm{n}$ & $\%$ & \\
\hline Origin & & & & & 0.992 \\
\hline Aracaju & 12 & 41.3 & 17 & 58.6 & \\
\hline Countryside & 26 & 38.8 & 41 & 61.1 & \\
\hline Age (years) & & & & & 1.000 \\
\hline $10-14$ & 3 & 42.8 & 4 & 57.1 & \\
\hline $15-19$ & 35 & 39.3 & 54 & 60.6 & \\
\hline Marital status & & & & & 0.024 \\
\hline Stable union & 37 & 44.0 & 47 & 56.0 & \\
\hline Without stable union & 1 & 8.3 & 11 & 91.7 & \\
\hline Education level & & & & & 0.028 \\
\hline Did not conclude elementary schooling & 30 & 49.1 & 31 & 50.8 & \\
\hline Concluded elementary schooling & 1 & 20.0 & 4 & 80.0 & \\
\hline Did not conclude high school & 7 & 30.4 & 16 & 69.5 & \\
\hline Concluded high school & 0 & - & 7 & 100.0 & \\
\hline Occupation & & & & & 0.472 \\
\hline Paying job & 2 & 25.0 & 6 & 75.0 & \\
\hline Non-paying job & 36 & 40.9 & 52 & 59.0 & \\
\hline Income (minimum wages) & & & & & 0.938 \\
\hline$\leq 1$ & 27 & 38.5 & 43 & 61.4 & \\
\hline $2-3$ & 8 & 42.1 & 11 & 57.8 & \\
\hline$>3$ & 3 & 42.8 & 4 & 57.1 & \\
\hline Pregnancy (parity) & & & & & 1.000 \\
\hline 1 & 30 & 39.4 & 46 & 60.5 & \\
\hline$\geq 2$ & 8 & 40.0 & 12 & 60.0 & \\
\hline Prenatal consultation & & & & & 0.747 \\
\hline $1-3$ & 12 & 42.8 & 16 & 57.1 & \\
\hline $4-6$ & 15 & 35.7 & 27 & 64.2 & \\
\hline$\geq 7$ & 11 & 44.0 & 14 & 56.0 & \\
\hline None & 0 & - & 1 & 100.0 & \\
\hline Pregnancy planning & & & & & 0.191 \\
\hline No & 24 & 34.7 & 45 & 65.2 & \\
\hline yes & 14 & 51.8 & 13 & 48.1 & \\
\hline
\end{tabular}

outcomes such as prematurity and restricted intrauterine growth. This refers to the drop in the concentrations of folate (folic acid) from the $5^{\text {th }}$ month of gestation and that persists for a long period after childbirth. Thus, women who became pregnant before the replacement of folate stocks would be more prone to these outcomes. ${ }^{15}$

Primiparous women usually have children with an average birth weight lower than multiparous. However, most multiparous women are more prone to shorter interpregnancy intervals, an important risk factor for low birth weight, prematurity, neonatal and infant mortality and childhood malnutrition. In addi- tion, the exposed study reinforces the link between primiparity and mothers aged 15 to 19 years old. Parity and the interpregnancy interval imply risks in different magnitudes for women and newborns, since the tendency is that primiparous women have babies with a lower average birth weight than multiparous women, especially if the first pregnancy occurs at adolescence, in accordance with the findings of this study. 5

Considering that the calculation of gynecological age is obtained by subtracting the chronological age from the age of the menarche, 16 it was found that in a relevant number of teenage mothers 
$(40.5 \%)$ it was less than or equal to two years. In a survey conducted in Rio de Janeiro, with teenage mothers aged 13 to 19 years old, it showed that $48.3 \%$ had a gynecological age less than or equal to two years. ${ }^{17}$ By combining all these data, it is possible to state that adolescents are starting earlier and earlier their sexual life due to the curiosity to try the new so exposed nowadays by the media, for the acceleration of biological and sexual maturation, for the early exposure of pregnancy, for the lack of knowledge, for not using contraceptive methods and, in addition, for the lack of dialogue with their parents about this issue.

The lower the gynecological age, the higher the risk for pregnancy, due to immaturity of uterine vascularization, which would result in premature delivery or an insufficient placenta. 10

Pregnancy planning and a stable relationship with the partner are factors that are generally closely correlated. In the results found, the marital condition showed a significant relationship between the woman's gynecological age and the occurrence of LBW ( $p=0.024)$, so studies report that a stable relationship favors the non-use of contraceptive methods and a more active sexual practice, and exposes the woman to an early unplanned pregnancy, as well as being infected by sexually transmitted diseases. In case of the teenagers, it contributes to the high rates of early pregnancy and their risk conditions, such as low birth weight in newborns. 17

The younger the gynecological age, the more susceptible to risks this teenager is, due to factors such as early menarche and chronological age of low pregnancy, increased sexual freedom, failure in sexual education and fragile family space that leads to the search for a bond with a partner and an early autonomy. ${ }^{17}$ In this study, in general $70.2 \%(n=163)$ of mothers had unplanned pregnancies, which corroborates a study carried out at the General Hospital in Caxias do Sul, at the University Hospital at the Universidade Federal do Maranhão (HUUFMA), in city of Santo André by the Fundação Sistema Estadual de Análise de Dados (SEADE) (State Data Analysis System Foundation) and the Santa Maria University Hospital (HUSM) and Casa de Saúde Hospital (HCS). 3,6,7,13

In the sample analyzed, there was a predominance of low level of schooling in the mentioned age group, which shows a discrepancy between age / school grade, so that $63.3 \%$ had not concluded primary schooling, when they should have been attending or completed high school, a fact that corroborates a study based on a bibliographic review of 34 articles, in which the authors report that in
Brazil, there is a close relationship between education and motherhood. Results on Pesquisa Nacional por Amostra de Domicílios (PNAD) (National Household Sample Survey) show a higher frequency of pregnancies in teenagers aged 15 to 19 years old without schooling. 18 Furthermore, in the present study, there was a high frequency of teenagers without a paying job (79.3\%), the evidence is that early pregnancy brings as a main socioeconomic consequence of dropping out of school, a situation that constitutes an important condition of delay in schooling, as teenagers have to prioritize the care of the baby, causing difficulties in accessing the work market. 18 There is a lack of academic skills in teenagers which were understood as the information from learning enables them to access knowledge, by allowing them to update new learning and be inserted in the contemporary world. 19

In the group of mothers who had babies with low birth weight, it was observed that $49.1 \%$ had incomplete primary schooling and had a gynecological age of less than 2 years. By relating the period of early menarche and low gynecological age $(\leq 2)$ as a reference for sexual and intellectual immaturity, we can assess teenagers' behavior with low schooling as a decisive factor for the lack of knowledge regarding pregnancy prevention. The factors described above contribute to the perpetuation of low socioeconomic stratum, poverty and limited education. 18

In the United States, LBW is the second leading cause of infant mortality. Women with low socioeconomic status are at the increased risk of having low birth weight babies. The rate of low weight babies of teenage mothers is $35 \%$ higher than those aged 20 to 29 years old. Becoming a mother within two years of menarche increases the risk of preterm birth. Many pregnancies among adolescents are unwanted, unplanned and are discovered later. Teenage mothers are more prone to poverty, low educational level and lack of access to services than older mothers, all of which, there are risk factors for low birth weight within themselves. ${ }^{20}$

The socioeconomic and obstetric risk factors analyzed were relevant to the occurrence of low birth weight, as they intensify the condition of vulnerability typical in teenagers. Among these, it was found that the bond with the partner and education were the variables with the greatest strength to influence the outcome of the event, since stable relationships at this stage of life favor carelessness in the use of contraceptive methods, as well as a more active sexual practice intercourse, which increases the chances of an unplanned pregnancy. Schooling has an inverse relation with the issue of self-care, 
because the lower the level of knowledge, the higher the exposure of risky situations and health problems, such as teenage pregnancy and low birth weight.

\section{Authors' contribution}

Santos BK and Barreto VMM worked on the preparation of the project, data collection and analysis and of the article. Santos VS contributed to the writing and formatting the article. Prado NMCS performed data analysis and writing of the manuscript. Silva JRS performed the statistical analysis and the interpretation of the data. Bispo AJB provided data and contributed to the writing of article. Soares AF participated in the preparation of the project, data analysis and writing of the manuscript. All authors approved the final version of the article.

\section{References}

1. Gurgel MGI, Pineiro PNC, Alves MDS, Barroso GT, Vieira NFC. Gravidez na adolescência: tendência na produção científica de enfermagem. Esc Anna Nery Rev Enferm. 2008; 12 (4): 799-805.

2. WHO (World Health Organization). International classification of diseases. 9th revision. Geneva: WHO Library; 1975 .

3. Duarte CM, Nascimento VB, Akeman M. Gravidez na adolescência e exclusão social: análise de disparidades intra-urbanas. Rev Panam Salud Publica. 2006; 19 (4): 23643.

4. Organização Mundial da Saúde. CID-10. Classificação estatística internacional de doenças e problemas relacionados à saúde. $10^{\circ}$ Revisão. São Paulo: EDUSP; 1998. p. 1184.

5. Franceschini SCC, Priore SE, Pequeno NPF, Silva DG, Sigulem DM. Fatores de risco para o baixo peso ao nascer em gestantes de baixa renda. Rev Nutr. 2003; 16 (2): 171-9.

6. Ferraz TR, Neves ET. Fatores de risco para baixo peso ao nascer em maternidades públicas: um estudo transversal. Rev Gaúcha Enferm. 2011; 32 (1): 86-92.

7. Santos GHN, Martins MG, Sousa MS. Gravidez na adolescência e fatores associados com baixo peso ao nascer. RevBras Ginecol Obstet. 2008; 30 (5): 224-31.

8. UNFPA. Gravidez na Adolescência no Brasil. Fundo de Populações das Nações Unidas; 2013.

9. DATASUS. Rede Interagencial de Informações para a saúde. Proporção de nascidos vivos com peso ao nascer, 2011. [Acesso em 21 julho 2016]. Disponível em: http://tabnet.datasus.gov.br/cgi/tabcgi.exe?idb2012/g16.def

10. Bruno ZV. Gravidez na adolescência. Sem data de publicação. [Acesso em 24 de setembro de 2016]. Disponível em: http://www.sbpcnet.org.br/livro/57ra/programas/CONF _SIMP/textos/zenildabruno.

11. IBGE (Instituto Brasileiro de Geografia e Estatística). Indicadores sociodemográficos e de saúde no Brasil. Estudos e Pesquisas/Informação demográfica e socioeconômica. Rio de Janeiro; 2009. N ${ }^{\mathrm{o}} 25$.
12. Andrade CLT, Gama GN, Leal C. Desigualdades sócioeconômicas do baixo peso ao nascer e da mortalidade perinatal no Município do Rio de Janeiro. Cad Saúde Pública. 2004; 20 (Supl. 1): S44-S51.

13. Araújo BF, Tanaka ACA. Fatores de risco associados ao nascimento de recém-nascidos de muito baixo peso em uma população de baixa renda. Cad Saúde Pública. 2007; 23 (12): 2869-77.

14. Costa TJNM, Heilborn,ML. Gravidez na adolescência e fatores de risco entre filhos de mulheres nas faixas etárias de 10 a 14 e 15 a 19 anos em Juiz de Fora, MG. Rev APS. 2006;9 (1): 29-38.

15. Sgroi JCL. Relação de fatores de risco na gestação e peso ao nascer em crianças atendidas no Centro de Saúde Escola do Butantã, cidade de São Paulo [Dissertação]. São Paulo: Faculdade de Medicina da Universidade de São Paulo; 2008.

16. Junior SJF, Filho JF. A menarca e seu impacto nas qualidades físicas de escolares. Rev Saúde Pública. 2013; 15 (2): 281-93.

17. Spindola T, Silva LFF. Perfil epidemiológico de adolescente atendidas no pré-natal de um Hospital Universitário. Esc Anna Nery Rev Enfem. 2009; 13 (1): 99-107.

18. Costa EL, Sena MCF, Dias A. Gravidez na adolescência determinante para prematuridade e baixo peso. Com Ciênc Saúde. 2011; 22 (Supl. 1): S183-S188.

19. Nascimento IP, Morais KAF, Silva TP. Adolescentes grávidas acompanhadas em uma unidade de saúde da família: análise de suas representações sociais sobre a escola. Rev Adolesc Saúde. 2011. 8 (4): 27-34.

20. Reichman NE. Low birth weight and school readiness. 2005; 15 (1): 91-116. Disponível em: <www.futureofchildren.org $>$.

Received on September 28, 2018

Final version presentedon August 1, 2019

Approved on December 19, 2019 